\title{
PERBEDAAN KADAR ELASTASE KANALIS SERVIKALIS ANTARA KEHAMILAN DENGAN ANCAMAN PERSALINAN PRETERM DAN KEHAMILAN NORMAL
}

\author{
Jusuf Sulaeman Effendi \\ Bagian Obstetri dan Ginekologi Fakultas Kedokteran Universitas Padjadjaran \\ Rumah Sakit Hasan Sadikin Bandung
}

\begin{abstract}
ABSTRAK
Elastase diketahui berperan dalam mengubah kondisi serviks wanita hamil yaitu menyebabkan serviks menjadi lunak, mendatar, dan membuka yang merupakan tanda bahwa proses persalinan sedang terjadi. Penelitian ini bertujuan untuk mengetahui perbedaan kadar elastase kanalis servikalis antara kehamilan dengan ancaman persalinan preterm dan kehamilan normal. Penelitian ini adalah penelitian potong silang pada 32 kasus ancaman persalinan preterm dan 34 kasus kehamilan normal yang disesuaikan dalam hal usia, paritas dan usia kehamilan periode Januari 2004-Februari 2005. Kriteria ancaman persalinan preterm berdasarkan Buku Pedoman Diagnosis dan Terapi Obstetri dan Ginekologi RS Dr. Hasan Sadikin Bandung. Kadar elastase kanalis servikalis diperiksa dengan metode ELISA dan diuji pada interval kepercayaan 95\%. Didapatkan hasil rerata kadar elastase kanalis servikalis kelompok kasus ancaman persalinan preterm sebesar $1,72 \mathrm{ng} / \mathrm{mL}$, lebih tinggi secara bermakna dibandingkan dengan rerata kadar elastase kanalis servikalis kehamilan normal sebesar $0,52 \mathrm{ng} / \mathrm{mL}(\mathrm{p}=0,002)$. Didapatkan cut-off point kadar elastase kanalis servikalis untuk memprediksi terjadinya ancaman persalinan preterm dengan sensitivitas $87,5 \%$, spesifisitas $52,9 \%$, dan akurasi $69,7 \%$.
\end{abstract}

Kata kunci: Elastase kanalis servikalis, persalinan preterm

\section{THE DIFFERENCE OF ELASTASE CONCENTRATION IN CANALIS CERVICALIS BETWEEN THREATENED PRETERM LABOR AND NORMAL PREGNANCY}

\begin{abstract}
Elastase has a role in changing cervix condition in pregnancy as like as softening, effacement and dilatation and both are the signs of labor. The objective of this study was to know the difference of elastase concentration in canalis cervicalis between threatened preterm labor and normal pregnancy. A cross sectional study was done involving 32 patients with threatened preterm labor and 34 normal pregnant women as control has been done during January 2004 to February 2005. Some variables such as maternal age, gestational age and parity were matched for both groups. The criteria of threatened preterm labor is taken from Obstetry and Gynecology Protocol in Hasan Sadikin Hospital. Elastase concentration in canalis cervicalis was examined by ELISA method with $95 \%$ considered statistically significant. The mean value of elastase concentration in canalis cervicalis of threatened preterm labor women 1.72 $\mathrm{ng} / \mathrm{mL}$ was significantly higher than that observed in normal pregnancy $0.52 \mathrm{ng} / \mathrm{mL}(\mathrm{p}=0.002)$. It was found the cut-off point elastase concentration in canalis cervicalis as predictor in threatened preterm labor is $0.52 \mathrm{ng} / \mathrm{mL}$ with sensitivity $87.5 \%$, specificity $52.9 \%$ and accuracy $69.7 \%$.
\end{abstract}

Key words: Elastase canalis cervicalis, preterm labor

Alamat Korespondensi

Dr. dr. Jusuf Sulaeman Effendi, SpOG(K)

Bagian Obstetri dan Ginekologi Fakultas Kedokteran Universitas Padjadjaran/RSHS

Jl Pasteur no.38 Bandung

Telp: (022) 2032530 


\section{PENDAHULUAN}

Persalinan preterm, yaitu persalinan yang terjadi pada usia kehamilan 20 minggu atau lebih sampai dengan kurang dari 37 minggu, bervariasi angka kejadiannya antara $5 \%$ sampai dengan $12 \%$ dari seluruh persalinan. ${ }^{1}$ Kematian bayi yang dilahirkan preterm merupakan $70 \%$ dari seluruh kematian bayi dan di RS. Hasan Sadikin Bandung menjadi $56,6 \%$ dari seluruh penyebab kematian perinatal. ${ }^{2,3}$ Upaya menurunkan angka kematian perinatal khususnya yang terjadi pada bayi preterm di Indonesia belum memberikan hasil yang memuaskan, terkendala dengan faktor sarana dan biaya yang sangat tinggi.

Upaya yang sekarang sedang digalakkan adalah mencegah terjadinya persalinan preterm melalui pencegahan primer, sekunder, maupun tersier. Upaya pencegahan tersier yaitu dengan memberikan pengobatan tokolitik pada pasien dengan gejala persalinan preterm sudah dilakukan meskipun masih memberikan hasil pemanjangan masa kehamilan yang tidak memuaskan. Pada saat ini sedang dikembangkan upaya pencegahan sekunder berupa deteksi dini untuk kemungkinan terjadinya persalinan preterm melalui penilaian kontraksi rahim dan penilaian serviks.

Dasar patofisiologi terjadinya persalinan preterm yang saat ini banyak dianut adalah terjadinya proses inflamasi di dalam kompartemen kehamilan. Akibat proses inflamasi akan terjadi pengaktifan jejaring sitokin (cytokine network) dengan dikeluarkannya berbagai sitokin seperti interleukin (IL-1), IL-6, IL-8, dan tumor neucrosis factor $\alpha$ (TNFa) yang selanjutnya akan menyebabkan bergeraknya sel polymorphonuclear leukocyte (PMN) kedalam kompartemen kehamilan termasuk dalam serviks uteri. Sel PMN ini dalam proses selanjutnya akan mengeluarkan suatu enzim yang disebut granulocyte elastase yang bekerja memecah matriks ekstraselular dalam jaringan koriodesidua dan serviks uteri. $^{4-7}$

Berdasarkan pemikiran tersebut maksud penelitian ini untuk mengetahui perubahan kadar elastase dalam kanalis servikalis pada pasien dengan ancaman persalinan preterm.

\section{METODE}

Rancangan penelitian yang dilakukan adalah potong silang. Penelitian dilakukan di RS Dr. Hasan Sadikin Bandung mulai Januari 2004 sampai dengan Februari 2005. Populasi penelitian adalah kasus yang memenuhi kriteria ancaman persalinan preterm, yaitu usia kehamilan antara 28 minggu sampai dengan kurang dari 37 minggu, adanya kontraksi uterus dengan interval $<10$ menit, didapatkan pembukaan serviks $4 \mathrm{~cm}$ atau kurang dan selaput ketuban masih utuh. Pada waktu yang bersamaan dilakukan pemilihan kasus pasien hamil normal sebagai kontrol yang memenuhi kriteria secara random dengan usia kehamilan, usia ibu, dan paritas yang disesuaikan dengan kasus (matching).

Semua wanita hamil baik kelompok dengan ancaman persalinan preterm maupun kelompok hamil normal (tanpa ancaman persalinan preterm) harus memenuhi kriteria inklusi dan tak termasuk kriteria eksklusi. Kriteria inklusi adalah hamil tunggal, anak hidup dan diketahui pasti usia kehamilannya, sedangkan kriteria eksklusi adalah wanita hamil yang menggunakan cerclage, ada komplikasi medis dalam kehamilannya, ada kelainan kongenital pada janin, riwayat melahirkan kurang bulan, dan riwayat abortus pada kehamilan trimester I.

Kedua kelompok yang bersedia mengikuti penelitian diminta untuk menandatangani formulir yang telah disediakan. Pada kedua kelompok penelitian dilakukan pengambilan lendir dari kanalis servikalis yang selanjutnya akan dilakukan pemeriksaan kadar elastase kanalis servikalisnya. Selanjutnya sampel lendir kanalis servikalis diperiksa dengan metode ELISA dan ditentukan kadar elastasenya.

\section{HASIL}

Selama periode penelitian tersebut telah terkumpul sebanyak 32 kasus ancaman persalinan preterm dan 34 pasien kontrol yang matching dalam hal usia, paritas, dan usia kehamilan.

Tabel 1 menyajikan karakteristik subjek penelitian, meliputi usia ibu, paritas, dan usia kehamilan pada saat penelitian.

Dari segi usia ibu, sebagian besar berada pada usia di antara 20-35 tahun yang merupakan usia reproduksi yang optimal. Perbedaan penyebaran kedua kelompok ini tidak berbeda bermakna secara statistik $(p>0,05)$.

Dari segi paritas, sebagian besar kedua kelompok berasal dari paritas 0 yaitu sebanyak setengahnya atau lebih untuk masing-masing kelompok. Tidak didapatkan perbedaan yang bermakna secara statistik antara kedua kelompok dilihat dari segi paritas $(p>0,05)$. Dari segi usia kehamilan pada saat penelitian dilakukan, sebanyak $50 \%$ kelompok pasien hamil normal berada pada usia kehamilan antara 31-33 minggu, sedangkan sebagian besar pada kelompok pasien ancaman persalinan preterm mempunyai usia kehamilan 34-36 minggu. Walaupun demikian penyebaran penderita menurut kelompok usia kehamilan pada kedua kelompok ini tidak menunjukkan perbedaan yang bermakna secara statistik $(p>0,05)$.

Berdasarkan homogenitas data dasar di atas, maka kedua kelompok layak diperbanding- 
Tabel 1 Karakteristik Subjek Penelitian

\begin{tabular}{cccc}
\hline \multirow{2}{*}{ Ka rakteristik } & \multicolumn{2}{c}{ Kelompok } & Kemaknaan \\
\cline { 2 - 3 } & $\begin{array}{c}\text { Ancaman PP } \\
(\mathbf{n}=\mathbf{3 2})\end{array}$ & $\begin{array}{c}\text { Hamil Normal } \\
(\mathbf{n}=\mathbf{3 4})\end{array}$ & \\
\hline Usia (tahun) & & & \\
$<20$ & 4 & 1 & \\
$20-24$ & 7 & 8 & \\
$25-29$ & 6 & 10 & \\
$30-34$ & 9 & 6 & $\mathrm{t}=0,93$ \\
$\geq 35$ & 5 & $28,9(6,3)$ & $\mathrm{p}=0,355$ \\
$\overline{X(S B)}$ & $27,5(6,2)$ & & \\
Paritas & & 18 & $\mathrm{X}^{2}=0,06$ \\
& 16 & 15 & $\mathrm{p}=0,972$ \\
0 & 15 & 1 & \\
1-3 & 1 & & \\
Usia Kehamilan (mg) & & 10 & $\mathrm{t}=0,76$ \\
$28-30$ & 10 & 17 & $\mathrm{p}=0,448$ \\
$31-33$ & 8 & 7 &
\end{tabular}

Keterangan: $\mathrm{t}=\mathrm{uji} \mathrm{t} ; \mathrm{X}^{2}=$ uji chi-kuadrat.

Tabel 2 Hasil Pemeriksaan Konsentrasi Elastase dalam Kanalis Servikalis pada Kedua Kelompok Penelitian

\begin{tabular}{clll}
\hline \multirow{2}{*}{$\begin{array}{c}\text { Konsentrasi Elas tase } \\
(\mathbf{n g} / \mathbf{m L})\end{array}$} & \multicolumn{2}{c}{ Kelompok } & Kemaknaan \\
\cline { 2 - 3 } & \multicolumn{1}{c}{$\begin{array}{c}\text { Kasus } \\
(\mathbf{n}=\mathbf{3 2})\end{array}$} & $\begin{array}{l}\text { Kontrol } \\
(\mathbf{n}=\mathbf{3 4})\end{array}$ & \\
\hline $\bar{X}(\mathrm{SB})$ & $2,68(3,99)$ & $1,31(1,94)$ & $\mathrm{Z}_{\mathrm{M}-\mathrm{W}=3,06}$ \\
Median & 1,72 & 0,52 & $\mathrm{p}=0,002$ \\
Rentang & $0,09-22,07$ & $0,11-9,98$ & \\
\hline
\end{tabular}

Keterangan: $Z_{M-W}=U j i$ Mann-Whitney.

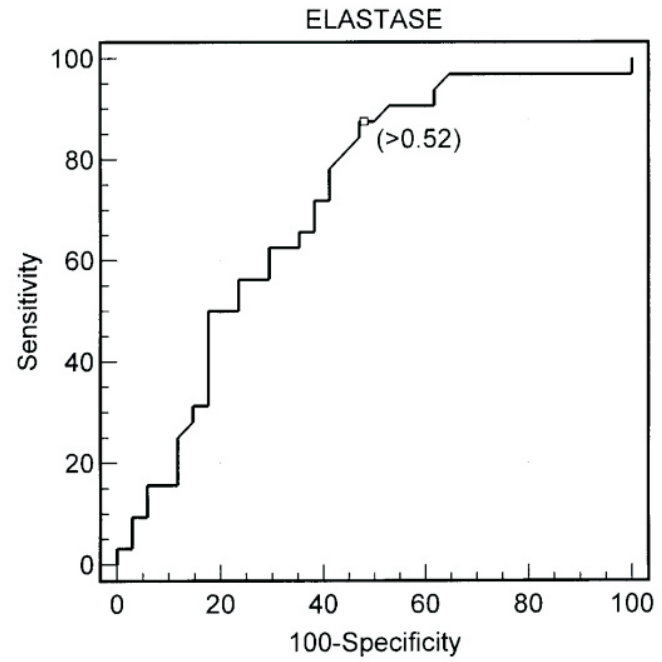

Gambar Kurva Receiver Operating Characteristic Nilai Elastase

kan.

Tabel 2 memperlihatkan perbedaan konsentrasi elastase dalam kanalis servikalis antara kelompok wanita hamil dengan ancaman persalinan preterm dan wanita hamil normal. Pada kelompok wanita hamil dengan ancaman persalinan preterm didapatkan kadar elastase $1,72 \mathrm{ng} / \mathrm{mL}$ dibandingkan dengan kadar elastase pada kelompok hamil normal sebesar 0,52 
$\mathrm{ng} / \mathrm{mL}$. Perbedaan kadar elastase kanalis servikalis antara kedua kelompok ini bermakna secara statistik $(p=0,002)$.

Gambar memperlihatkan 8 konsentrasi elastase dalam kanalis servikalis yang didisain sebagai cut-off point kemudian dianalisis pada kedua kelompok penelitian. Pada berbagai konsentrasi elastase ini dinilai sensitivitas, spesifisitas, dan tingkat akurasinya. Dari kedelapan konsentrasi elastase yang dinilai untuk dijadikan cut-off point untuk meramalkan kejadian persalinan preterm, konsentrasi elastase $0,52 \mathrm{ng} / \mathrm{mL}$ yang terpilih sebagai nilai cut-off point dengan sensitivitas $87,5 \%$, spesifisitas 52,9\%, dan tingkat akurasi $69,7 \%$. Apabila dipilih konsentrasi elastase dengan sensitivitas lebih tinggi, maka spesifisitasnya akan semakin kecil sementara tingkat akurasinya tidak mengalami banyak perubahan. Kemudian dicoba untuk menyusun kedelapan nilai elastase kanalis servikalis ini kedalam kurva receiver operating characteristic seperti tergambar dalam kurva.

Setelah kedelapan nilai elastase ini disusun kedalam kurva ROC (receiver operating characteristic), ternyata nilai elastase yang ke-7 yaitu dengan konsentrasi $0,52 \mathrm{ng} / \mathrm{mL}$ mempunyai jarak terjauh bila diambil tegak lurus terhadap garis diagonal kurva. Dengan demikian cut-off point yang diambil adalah konsentrasi elastase kanalis servikalis sebesar $0,52 \mathrm{ng} / \mathrm{mL}$.

\section{PEMBAHASAN}

Pemilihan pasien dalam penelitian ini didasarkan pada pertimbangan untuk mendapatkan pasien yang tidak mempunyai faktor risiko untuk terjadinya persalinan preterm seperti yang tercantum di dalam kriteria inklusi dan kriteria eksklusi. Kelompok ancaman persalinan preterm maupun kelompok hamil normal yang dimasukkan dalam penelitian ini adalah wanita hamil dengan usia kehamilan $\geq 28$ minggu dan kurang dari 37 minggu sehingga termasuk kelompok kehamilan kurang bulan. Untuk menghilangkan faktor perancu yang mungkin ada dan tidak dapat disingkirkan dengan cara pemisahan tersebut di atas, maka disingkirkan dengan cara matching. Faktor-faktor tersebut antara lain adalah usia, paritas, dan usia kehamilan pada saat dilakukan penelitian pada kedua kelompok tersebut. Ketiga faktor tersebut dianggap faktor yang paling besar kemungkinannya menjadi perancu pada penelitian ini.

Selain usia, paritas, dan usia kehamilan masih banyak lagi faktor yang dapat mempengaruhi validitas penelitian ini seperti suku bangsa, berat badan ibu, sosio-ekonomi, status pekerjaan, dan jenis kelamin janin yang dikandung. Akan tetapi, mengingat akan persyaratan minimal untuk memperoleh validitas internal dan eksternal yang memadai agar dapat memenuhi populasi sasaran dan populasi terjangkau yang diinginkan, maka hanya ketiga faktor tersebut di atas yang dipilih untuk disingkirkan dengan cara matching.

Penelitian ini menggunakan studi potong silang dengan mencari kasus yang memenuhi kriteria ancaman persalinan preterm di RS dr. Hasan Sadikin Bandung sampai mencapai jumlah kasus yang diinginkan, dan bersamaan dengan itu dilakukan pencarian pasien kontrol secara random. Selama periode waktu satu tahun didapatkan sebanyak 34 pasien ancaman persalinan preterm dan 32 pasien sebagai kontrol. Ternyata semua subjek baik dari kelompok pasien dengan ancaman persalinan preterm maupun kelompok pasien hamil normal memenuhi syarat untuk perhitungan selanjutnya, sehingga jumlah seluruhnya adalah 66 subjek.

Elastase adalah suatu protease yang bekerja memecah protein yang dikandung dalam matriks ekstraselular dan dihasilkan oleh neutrofil. Enzim ini didapatkan di dalam kompartemen kehamilan mulai awal kehamilan dalam jumlah yang rendah. Konsentrasi yang rendah ini didapatkan sampai usia kehamilan 34 minggu. Kenaikan kadar elastase yang bermakna baru terjadi sesudah usia kehamilan 34 minggu dan mencapai kadar $1 \mathrm{ng} / \mathrm{mL}$ pada usia kehamilan 37 minggu. ${ }^{5}$ Enzim ini di dalam serviks mempunyai kemampuan memecah matriks ekstraselular yang menyebabkan serviks menjadi matang, yaitu mengalami pendataran dan pembukaan yang biasanya terjadi pada saat persalinan. ${ }^{5,6}$ Aktivitas enzim ini di dalam kompartemen kehamilan termasuk serviks uteri dihambat oleh suatu inhibitor yang disebut secretory leucocyte protease inhibitor (SLPI), dan pada keadaan normal sebelum memasuki masa persalinan terdapat keseimbangan antara konsentrasi elastase dan konsentrasi SLPI sehingga elastase tidak menunjukkan peranannya merusak integritas matriks ekstraselular korion, amnion, dan serviks.

Pada persalinan preterm sebagai respons terhadap adanya proses inflamasi di dalam kompartemen kehamilan, sel neutrofil akan dikerahkan ke lokasi inflamasi dalam jumlah yang banyak akibat pengaktifan jejaring sitokin karena adanya proses inflamasi tersebut. Pada tempat-tempat inflamasi tersebut sel neutrofil akan diaktifkan dan mengalami lisis, sehingga elastase yang berada di dalam granul azurofilik neutrofil akan keluar. Pada persalinan preterm yang diakui kejadiannya didasarkan atas adanya proses inflamasi di dalam kompartemen kehamilan, konsentrasi elastase akan meningkat seiring dengan bertambahnya sel neutrofil. Terjadi ketidak-seimbangan antara elastase dan SLPI, sehingga SLPI tidak mampu menghambat aktivitas elastase tersebut, dan 
pada akhirnya enzim ini akan menghancurkan kandungan protein dalam matriks ekstraselular dari korion amnion dan serviks uteri. Sebagai akibat dari keadaan ini akhirnya akan menyebabkan pecahnya selaput korion-amnion dan perubahan pada serviks berupa pembukaan dan pendataran. Proses inflamasi di dalam kompartemen kehamilan juga akan menyebabkan sitokin-sitokin inflamasi menunjukkan peranannya dalam pembentukan uterotonin (prostaglandin) yang akan menyebabkan diaktifkannya reseptor oksitosin. Terbentuknya reseptor oksitosin akan menyebabkan oksitosin dapat bekerja untuk menyebabkan kontraksi rahim. Rusaknya integritas matriks ekstraselular di jaringan tersebut yang disertai meningkatnya konsentrasi prostaglandin pada kompartemen kehamilan akan lebih memperbesar kemungkinan untuk terjadinya proses persalinan.

Dari Tabel 2 tampak bahwa terdapat perbedaan yang bermakna konsentrasi elastase kanalis servikalis antara wanita hamil dengan ancaman persalinan preterm dan wanita hamil normal $(p=0,002)$. Rata-rata konsentrasi elastase pada ancaman persalinan preterm adalah $1,72 \mathrm{ng} / \mathrm{mL}$, konsentrasi ini lebih besar dibandingkan dengan konsentrasi pada hamil normal yang rata-rata kadarnya $0,52 \mathrm{ng} / \mathrm{mL}$. Limvarapuss et a ${ }^{5}$ dalam penelitiannya memeriksa konsentrasi elastase kanalis servikalis wanita hamil normal antara mulai usia kehamilan 20 minggu sampai 33 minggu mendapatkan konsentrasi elastase $0,40 \mathrm{ng} / \mathrm{mL}$ pada kehamilan 20 minggu sampai $0,48 \mathrm{ng} / \mathrm{mL}$ pada kehamilan 33 minggu. Pada usia kehamilan 34 meningkat menjadi $0,71 \mathrm{ng} / \mathrm{mL}$ dan $1,05 \mathrm{ng} / \mathrm{mL}$ pada kehamilan 37 minggu.

Pada penelitian ini didapatkan hasil $0,52 \mathrm{ng} / \mathrm{mL}$ pada kelompok hamil normal dengan rata-rata usia kehamilan 31,6 minggu yang tak jauh berbeda dengan hasil di atas.

Tampaknya pada konsentrasi elastase yang rendah dalam karnalis servikalis $(0,52 \mathrm{ng} /$ $\mathrm{mL}$ ), enzim ini tidak akan menunjukkan peranannya dalam merusak matriks ekstraselular jaringan serviks oleh karena adanya peranan SLPI selaku inhibitor enzim elastase. Sebaliknya pada konsentrasi elastase yang tinggi $(1,72$ $\mathrm{ng} / \mathrm{mL}$ ) terjadi ketidakseimbangan dengan SLPI sehingga elastase bekerja merusak matriks ekstraselular pada korion, amnion, dan serviks.

Dalam penelitian ini didapatkan variasi yang besar hasil pemeriksaan konsentrasi elastase pada kedua kelompok penelitian ini, yaitu dengan rentang $0,09-22,07 \mathrm{ng} / \mathrm{mL}$ untuk pasien dengan ancaman persalinan preterm dan 0,11-9,98 ng/mL pada kelompok hamil normal.

Penulis mencoba melakukan analisis untuk menjelaskan hal ini: Pemeriksaan konsentrasi elastase menggunakan standar sesuai dengan prosedur dan ketentuan yang diberlakukan oleh perusahaan pembuat kit elastase mulai dari pengambilan sampel, penyimpanan dan pemeriksaan konsentrasi elastase, sehingga diharapkan tidak ada kesalahan dalam pengukurannya. Tetapi tetap saja kemungkinan kesalahan pengelolaan sampel penelitian bisa terjadi pada keadaan ini; Pada kelompok ancaman persalinan preterm tampak beberapa sampel yang menunjukkan konsentrasi elastase kanalis servikalis yang rendah, yang diasumsikan seharusnya konsentrasinya tinggi. Pada keadaan ini mungkin karena ada faktor lain yang menyebabkan terjadinya gejala ancaman persalinan preterm, seperti kemungkinan peningkatan uterotonin yang menyebabkan kontraksi rahim, yang pembentukannya juga melalui jalur pengaktifan sitokin. Sebaliknya pada kelompok hamil normal tampak ada yang menunjukkan konsentrasi elastase yang tinggi, mungkin di sini oleh karena suatu sebab didapatkan konsentrasi SLPI yang tinggi sehingga terdapat keseimbangan dengan elastase; Pada kedua kelompok ada beberapa sampel yang memberikan hasil elastase yang sangat tinggi, baik pada kelompok ancaman persalinan preterm maupun kelompok hamil normal. Dalam kepustakaan dilaporkan bahwa konsentrasi elastase juga akan meningkat pada keadaan patologis tanpa melalui pengaktifan jejaring sitokin, misalnya pada emfisema paru, artritis reumatoid, dan beberapa penyakit lain. Apakah mungkin pada penelitian ini ada subjek penelitian yang ternyata mempunyai penyakit di atas tidak terdiagnosis pada saat pemilihan kasus ancaman persalinan preterm maupun hamil normal ?; Pada penelitian ini terdapat rentang yang lebar konsentrasi elastase kanalis servikalis pada kedua kelompok, sehingga penulis melakukan analisis hasil yang tidak berdistribusi normal ini dengan menggunakan uji statistik Mann-Whitney.

Dengan melihat keadaan di atas tampaknya konsentrasi elastase dalam kanalis servikalis harus dibandingkan dengan konsentrasi elastase darah untuk menyingkirkan kemungkinan peningkatan konsentrasi elastase yang sifatnya menyeluruh.

Pemeriksaan aktivitas elastase dalam kanalis servikalis saat ini masih belum dilakukan di Indonesia, tetapi dengan melihat hasilnya yang cukup baik untuk membedakan antara pasien ancaman persalinan preterm dari kehamilan normal tampaknya perlu dipikirkan untuk menerapkannya sebagai salah satu cara pemeriksaan pada pasien yang mempunyai risiko untuk terjadinya persalinan preterm. Mungkin perlu dikembangkan cara pembacaan hasil elastase yang lebih sederhana tanpa harus membawa sampel ke laboratorium, tetapi cukup melalui pembacaan hasil di tempat pasien tersebut diperiksa. Apabila hal ini bisa dilakukan, maka pemeriksaan aktivitas elastase dalam kanalis servikalis dapat dilakukan di fasilitas pelayanan primer. 
Dari penelitian ini didapat kesimpulan bahwa pemeriksaan konsentrasi elastase dalam kanalis servikalis memperlihatkan perbedaan yang sangat bermakna antara wanita hamil dengan ancaman persalinan preterm dan wanita hamil normal. Pada wanita hamil dengan ancaman persalinan preterm konsentrasi elastase kanalis servikalis $1,72 \mathrm{ng} / \mathrm{mL}$ jauh lebih tinggi dibandingkan dengan konsentrasi pada wanita hamil normal yaitu sebesar $0,52 \mathrm{ng} / \mathrm{mL}$.

Nilai cut-off point $0,52 \mathrm{ng} / \mathrm{mL}$ untuk konsentrasi elastase dalam kanalis servikalis dapat dipergunakan untuk meramalkan terjadinya persalinan preterm pada pasien hamil risiko tinggi untuk terjadinya persalinan preterm. Seperti dilaporkan dalam berbagai literatur bahwasanya pencegahan persalinan preterm sering mengalami kegagalan dalam memperpanjang masa kehamilan dengan maksud untuk menghasilkan bayi yang cukup bulan oleh karena proses patobiologis pada persalinan preterm sudah berlangsung. Semakin lama proses tersebut berjalan maka tingkat kegagalan pencegahan akan semakin tinggi. Dengan didapatkannya cutoff point untuk elastase dalam kanalis servikalis diharapkan akan meningkatkan keberhasilan pencegahan persalinan preterm.

\section{DAFTAR PUSTAKA}

1. Creasy RK. Preterm labor and delivery. Dalam: Creasy RK, Resnick R, editor. Maternal fetal medicine. Edisi ke-3. Philadephia: WB Saunders Co; 1994. h. 494-520.

2. Usman L, Effendi JS. Tinjauan kasus persalinan prematur di RSHS tahun 1998-
2000. PTP POGI XII, Palembang 2001.

3. Wiknyosastro G. Antenatal infection and preterm labour. J Pediatr Obstet Gynaecol. 1998;24(4):27-30.

4. Romero R, Avila C, Sepulveda W. The role of systemic and intrauterine infection in preterm labor. Dalam: Fuchs AR, Fuchs AF, Stubblefield $P G$, editor. Preterm birth causes, prevention and management. Edisi ke-2. New York: McGraw Hill, Inc; 1993. h. 97-136.

5. Limvarapuss C, Kanayama N, Terao T. Elastase activity of endocervical mucous in normal pregnancy. Asia Oceania J Obstetr Gynecol. 1992;18:147-53.

6. Lockwood CJ, Kuczynski E. Markers of risk for preterm delivery. J Perinat Med. 1999;27:5-20.

7. Abadi A. Keradangan selaput ketuban, plasenta dan interleukin-6 sebagai faktor penentu terjadinya persalinan pada persalinan kurang bulan membakat. Disertasi. Surabaya: Program Pasca Sarjana Universitas Airlangga; 1999.

8. Helmig BR, Romero R, Espinoza J, Chaiworapongsa T, Bujold E, Gomez R, et al. Neutrophyl elastase and secretory leukocyte protease inhibitor in prelabor rupture of membranes, parturition and intra-amniotic infection. J Mat Fetal Neonat Med. 2002;12:237-46.

9. Zhang Q, Shimoya K, Moriyama A, Yamanaka K, Nakajima A, Nobunaga T, et al. Production of secretory leucocyte protease inhibitor by human amniotic membranes and regulation of its concentration in amniotic fluid. Mol Hum Reprod. 2001;7(6):573-9. 